УДК 519.863:005.551

DOI: $10.15587 / 2313-8416.2015 .37398$

\title{
ВЕКТОРНА ОПТИМІЗАЦІЯ ОРГАНІЗАЦЙНОЇ СТРУКТУРИ СИСТЕМИ КЕРУВАННЯ
}

\author{
(C) В. К. Галіцин, О. П. Суслов, О. В. Остапчук
}

Наведена модель багатокритеріальної оптимізаџії ієрархічної структури керування з неоднорідними рівнозначними критеріальними показниками, щзо відображають структурну надмірність, неоднорідність розподілу зв'язків, структурну компактність і рівень централізації керування, реалізація якої здійснюється шляхом прийняття рішень на підставі графа Парето-оптимальних управлінь. Апробачія результатів дослідження здійснена на прикладі конкретного підприємства

Ключові слова: керування, організачійна структура, модель, критерій, цільвова функція, граф, вектор, зв'язок

It is given a model of multicriteria optimization in hierarchical control structure with mixed equivalent criteria indicators that reflect structural redundancy, heterogeneity of distribution of relations, structural compactness and control centralization level, the implementation of which is done by making decisions based on graph of Pareto-optimal controls. Approbation of the investigation results is carried out by the example of a particular company

Keywords: control, organizational structure, model, criteria, objective function, graph, vector, communications

\section{1. Ветуп}

Організаційна структура (OC) будь-якої системи керування - одне 3 ключових понять теорії керування, тісно пов'язане 3 метою, функціями, процесом керування, роботою менеджерів та розподілом між ними повноважень. У межах структури керування організаційною системою відбуваються всі управлінські процеси, в яких беруть участь менеджери всіх рівнів, категорій та професійної спеціалізації. Згідно з теорією систем структура відображає найсуттєвіші взаємовідносини між елементами та їхніми групами (компонентами, підсистемами), які несуттєво варіюють при змінах у системі i забезпечують існування системи та іiі основних властивостей.

Умови ринкового середовища вимагають нових підходів до керування: на перший план виходять постійні зміни в зовнішньому середовищі, що примушують організації розробляти складні системи керування, разом 3 бенчмаркінгом, реінжинірингом, аутсорсингом, використовують нові методи забезпечення керованості, найважливішим 3 яких $є$ оптимізація організаційної структури керування. Поява нових можливостей та небезпек, породжених зовнішнім середовищем, зумовлює виникнення в системі керування організацією додаткових задач та відповідну реакцію залежно від вектору змін.

Від побудови ефективної організаційної структури системи керування залежить майбутнє успішної та конкурентоспроможної організації.

2. Постановка проблеми оптимізації організаційної структури системи керування

Оптимальною слід вважати таку ОС, що забезпечує потрібні результати іiі функціонування найбільш економічним шляхом. Організаційна структура має бути стійкою до зовнішніх та внутрішніх збурень, гнучкою, забезпечувати оперативність управлінських рішень.
Оптимізація ОС має здійснюватися з урахуванням іiї властивостей, які можна відобразити через показники іiі ефективності: структурну надмірність, нерівномірність розподілу зв'язків, структурну компактність та рівень централізації керування.

Показник структурної надмірності характерризує перевищення загальної кількості зв'язків над мінімально необхідним для зв'язності між собою елементів системи (підрозділів організації) 3 метою виконання ними функцій, тобто відображає стійкість функціонування структури. Під стійкістю ОС розумітимемо можливості іiі здійснювати нормальне, безперебійне та ефективне функціонування у разі, коли вона піддається змінам внутрішнього та зовнішнього середовищ. Поняття стійкості ОС тісно пов'язане з поняттям її економічності.

Оптимальною і економічною організаційною структурою підприємства $€$ та, яка дає необхідні результати найбільш економічним шляхом. Економічну структуру отримують за рахунок зменшення числа ієрархічних рівнів керування, досягнення раціонального рівня централізації функцій, скорочення часу ухвалення рішень, впровадження програмноцільового підходу, підвищення іiї адаптивності.

Нерівномірність розподілу зв'язків часто зустрічається в організаційних структурах. Нерівномірний розподіл потоків, особливо фінансових, зустрічається постійно, що пов'язано 3 наявністю найбільш прибуткових підрозділів у межах однієї організації. Економічна неоднорідність структури $є$ однією з головних причин нерівномірності в розподілі економічних зв'язків.

Показник структурної компактності, який інколи ототожнюють 3 поняттям керованості, характеризує такий важливий параметр керування, як тривалість передання рішення керівного органу об'єкту керування. Цей показник пов'язаний зі взаємним розташуванням суб'єктів господарювання i каналів зв'язку між ними, за якими здійснюється 
керівний вплив та зворотний сигнал від керівного органу керованому підрозділу. Він $є$ мірою близькості суб'єктів господарювання, а також визначає кількість рівнів формування управлінських дій.

Індекс централізації визначає рівень централізації і тип системи керування. Чим вище його значення, тим більш жорстка та ієрархічна іiі ОС. У разі, якщо його значення близьке до одиниці, переважає жорсткий варіант керування, що супроводжується тотальним контролем з боку керівників за підлеглими. У разі близькості, або рівності його нулю, організаційна структура близька до децентралізованої або є повністю децентралізованою.

Використання розглянутих показників як цільових функцій моделі оптимізації організаційної структури системи керування вельми ускладнює іiі, оскільки передбачає необхідність усунення протиріч «стійкість - економічність», «рівномірність - нерівномірність у розподілі зв'язків», «компактність розгорнутість структури», «централізація - децентралізація керування». 3 метою усунення цих протиріч рекомендується використовувати багатокритеріальну (векторну) парадигму розв'язання поставленої проблеми із застосуванням теорії неорієнтованих графів.

\section{3. Літературний огляд}

Попри чималу кількість наукових публікацій з проблеми формування та вдосконаленням організаційної структури системи керування низки провідних учених (Р. Акбердін [1], Г. Ансофф [2], В. Бурков [3], Л. Свенко [4], Д Новіков [5], Б. Овсієвич [6], 3. Румянцева [7] та багато інших), науковий доробок яких вельми збагатив теорію ОС, проблема векторної оптимізації їх 3 урахуванням чинників внутрішнього і зовнішнього середовища залишається невирішеною остаточно, що спонукало авторів до публікації цієї статті.

4. Модель та алгоритм оптимізації організаційної структури системи керування

Розглядатимемо ОС у вигляді неорієнтованого графа [8], вершини якого $є$ елементами структури, а ребра - взаємозв'язки між ними.

Оптимізацію ОС здійснюватимемо за такими цільовими функціями:

структурна надмірність

$$
f_{1}(X)=\frac{1}{2(N-1)}\left(\sum_{i=1}^{N} \sum_{j=1}^{N} x_{i j}\right)-1 \rightarrow \max ,
$$

нерівномірність розподілу зв'язків

$$
\begin{gathered}
f_{2}(X)=\sum_{i=1}^{N} \sum_{j=1}^{N} x_{i j}-2 N \sum_{i=1}^{N} \sum_{j=1}^{N} x_{i j}\left(\sum_{i=1}^{N} \sum_{j=1}^{N} x_{i j}-\frac{N}{2}\right) \rightarrow \min , \\
\text { структурна компактність }
\end{gathered}
$$

$$
f_{3}(X)=\frac{\sum_{i=1}^{N} \sum_{j=1}^{N} x_{i j}^{*}}{N(N-1)}-1 \rightarrow \min , i \neq j,
$$

$$
\begin{aligned}
& \text { індекс централізації } \\
& f_{4}(X)=(N-1)\left\{2 \max \left[\frac{N(N-1)}{2 \sum_{i=1}^{N} x_{i j}^{*}}\right]-N\right\} \times \\
& \quad \times\left\{\max \left[\frac{N(N-1)}{2 \sum_{i=1}^{N} x_{i j}^{*}}\right](N-2)\right\} \rightarrow \max .
\end{aligned}
$$

Змінні величини $x_{i j} \epsilon$ елементами матриці суміжності, що відображає зв'язки елементів організаційної структури:

$$
X=\left\|x_{i j}\right\|, i=\overline{1, N}, j=\overline{1, N},
$$

де $N$ - множина індексів матриці змінних, тобто кількість елементів ОС. змінні

Елементами матриці суміжності $є$ булеві $x_{i j}=\left\{\begin{array}{l}1, \text { якщо вершина } x_{i} \text { суміжна } 3 \text { вершиною } x_{j}, \\ 0-\text { у протилежному випадку, }\end{array}\right.$ що означають наявність або відсутність зв'язку між суміжними вершинами графа.

Змінні величини $x_{i j}^{*} \epsilon$ елементами матриці мінімальних відстаней між вершинами графа $X^{*}=\left\|x_{i j}^{*}\right\| \quad(i=\overline{1, N}, \quad j=\overline{1, N})$, що визначають на підставі елементів матриці суміжності $X$. Якщо прийняти вагу кожного ребра за одиницю, то чисельно шлях дорівнюватиме кількості ребер графа, а мінімальний шлях - мінімальній їхній кількості:

$$
x_{i j}^{*}=\min \left\{x_{i j}, x_{i l}+x_{l j}\right\}, i, j, l=\overline{1, N} .
$$

Очевидно, потреба у формуванні матриці $X^{*}$ виникає у тому разі, коли існують альтернативні варіанти шляхів між несуміжними вершинами графа, в іншому разі передбачають, що $x_{i j}^{*}=x_{i j}$.

Наявність множини критеріальних показників змушує застосовувати модель багатокритеріальної оптимізації, за якої здійснюють інтегрування всіх показників у комплексний критерій (векторна оптимізація).

Розглянемо задачу векторної оптимізації організаційної структури.

Функціонування ОС спрямоване на досягнення цілей, що визначають вектором критеріїв:

$$
F(X)=\left\{f_{k}(X)\right\}_{k \in K},
$$

де $f_{k}(X)$ - частковий критерій; $k$ - індекс часткового критерію; $K-$ множина часткових критеріїв.

У моделі оптимізації ОС слід ураховувати обмеженість фінансових ресурсів. 
Нормативи витрат за підрозділами (вершини графа) і зв'язками між ними (ребра графа) задають вектором і матрицею витрат $A$ і $B$ відповідно:

$$
\begin{gathered}
A=\left(a_{1}, a_{2}, \ldots, a_{n}\right), \\
B=\left\|b_{i j}\right\|_{N \times N},
\end{gathered}
$$

де $a_{i}$ - елемент вектора $A$, що відображає сумарну величину витрат $i$-того підрозділу (витрати на утримання керівного апарату, експлуатацію технічних засобів, утримання приміщень, підготовку і перепідготовку керівних кадрів, одноразові витрати на дослідницькі та проектні роботи зі створення та удосконалення системи керування, на придбання комп'ютерної техніки та оргтехніки, що використовують у процесі керування, на будівництво тощо); $b_{i j}$ - елемент матриці $B$, який $\epsilon$ сумарною величиною витрат на здійснення зв'язку між елементами $i$ та $j$ ОС (витрати на виробництво, обслуговування потокових ліній, технологічних та інформаційних зв'язків тощо).

3 урахуванням цієї нормативної бази обмеження моделі оптимізації ОС 3 фінансових ресурсів має вигляд:

$$
\sum_{i=1}^{N} a_{i}+\sum_{i=1}^{N} \sum_{j=1}^{N} b_{i j} x_{i j} \leq R
$$

де $R$ - обсяг наявних фінансових ресурсів ОС.

Наявність мінімального набору вузлів структури потребує також наявності мінімально потрібного набору зв'язків:

$$
\sum_{i=1}^{N} \sum_{j=1}^{N} x_{i j} \geq 2 M_{\min }
$$

де $M_{\min }-$ мінімальна кількість взаємозв'язків системи.

Відомо [9], що для ОС системи з фіксованою кількістю вершин $N$ кількість зв'язків змінюється у межах:

$$
N-1 \leq \sum_{i=1}^{N} \sum_{j=1}^{N} x_{i j} \leq \frac{N(N-1)}{2} .
$$

Оскільки стабільний стан ОС залежить від наявності обов'язкових зв'язків між його елементами, то в модель включають обмеження:

$$
x_{i j}=p_{i j},
$$

де $p_{i j}$ - елемент матриці $P$ розмірності $N \times N$, яка характеризує сукупність обов'язкових зв'язків між елементами системи.

Отже, модель оптимізації ОС системи має вигляд:

$$
\text { opt } F(X)=\left\{\begin{array}{l}
\max F_{1}(X)=\left\{f_{1}(X), f_{4}(X)\right\} \\
\min F_{2}(X)=\left\{f_{2}(X), f_{3}(X)\right\}
\end{array}\right\}
$$

$$
\left\{\begin{array}{l}
\sum_{i=1}^{N} a_{i}+\sum_{j=1}^{N} b_{i j} \cdot x_{i j} \leq R \\
\sum_{i=1}^{N} \sum_{j=}^{N} x_{i j} \geq 2 \cdot M_{\min } \\
N-1 \leq \sum_{i=1}^{N} \sum_{j=}^{N} x_{i j} \leq \frac{N \cdot(N-1)}{2} \\
x_{i j}=p_{i j}, \mathrm{i}, j=\overline{1, N}
\end{array}\right.
$$

де $F_{1}(X)$ - векторний показник, кожен компонент якого максимізують; $F_{2}(X)$ - векторний показник, кожен компонент якого мінімізують.

Таким чином, задача оптимізації ОС полягає в тому, щоб побудувати матрицю неорієнтованого графа $X$, вершини якого пов'язані між собою так, щоб критерії досягали оптимальних значень 3 урахуванням обмежень (6).

Ця задача відноситься до класу задач багатокритеріальної оптимізації [10] 3 неоднорідними рівнозначними критеріальними показниками. Неоднорідність зумовлена наявністю в моделі як показників, що максимізують, так i тих, що мінімізують. Припущення щодо рівнозначності показників зумовлене тим, що кожен 3 них чинить суттєвий вплив на стан організаційної структури. Показник структурної надмірності пов'язаний зі стійкістю структури. Показник нерівномірності розподілу зв'язків пов'язаний 3 поняттям завантаженості елементів ОС. 3 показником структурної компактності пов'язано поняття структурної близькості елементів системи. Індекс централізації характеризує рівень централізації керування ОС.

Компромісний вибір ОС здійснюватимемо шляхом прийняття рішень на підставі графа Паретооптимальних управлінь [8] за такими етапами.

Eman 1. Визначення елементів матриці суміжності та матриці відстаней.

Eman 2. Однокритеріальна оптимізація структурри за кожним із критеріїв (1)-(4).

Eman 3. Обчислення за формулами (1)-(4) значень критеріальних показників для кожної структури, отриманої на етапі 2 без урахування інших показників, і виділення організаційних структур $\left(X_{m}, m=1,2,3,4\right)$, яким відповідає оптимальне значення відповідного критерію:

$$
\begin{aligned}
& X_{1}=\left\{f_{1}^{\max }(X), f_{2}^{1}(X), f_{3}^{1}(X), f_{4}^{1}(X)\right\}, \\
& X_{2}=\left\{f_{1}^{2}(X), f_{2}^{\min }(X), f_{3}^{2}(X), f_{4}^{2}(X)\right\}, \\
& X_{3}=\left\{f_{1}^{3}(X), f_{2}^{3}(X), f_{3}^{\min }(X), f_{4}^{3}(X)\right\}, \\
& X_{4}=\left\{f_{1}^{4}(X), f_{2}^{4}(X), f_{3}^{4}(X), f_{4}^{\max }(X)\right\},
\end{aligned}
$$

де $f_{k}^{m}(X)$ - значення $k$-того критеріального показника для структури $m$; $f_{k}^{\max }(X)=\max \left\{f_{k}^{m}(X)\right\}_{m=1,2,3,4}^{k=1,4}-$ максимальне значення показника, отримане в результаті вирішення однокритеріальної задачі оптимізації структури;

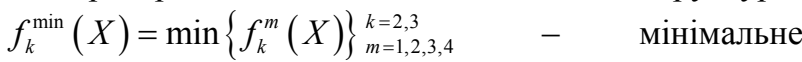


значення показника, отримане в результаті вирішення однокритеріальної задачі оптимізації структури.

Eman 4. Нормалізація критеріальних показників 3 метою приведення їх до однакової розмірності:

$$
\overline{f_{k}^{m}(X)}=\frac{f_{k}^{m}(X)-f_{k}^{\min }(X)}{f_{k}^{\max }(X)-f_{k}^{\min }(X)}, k=1,2,3,4 ; m=1,2,3,4,
$$

де $\overline{f_{k}^{m}(X)}$ - нормалізоване значення $k$-того показника структури $m ; f_{k}^{m}(X)$ - поточне значення $k$-того показника структури $m$.

Eman 5. Визначення величини приросту (зниження) $k$-того показника в результаті переходу системи від $r$-тої до $s$-тої структури:

$$
h_{\mathrm{k}}^{r \rightarrow s}=\overline{f_{k}^{s}(X)}-\overline{f_{k}^{r}(X)}, k=1,2,3,4, r=1,2,3,
$$

а індекс $s$ змінюють за правилом: при $r \quad 1 s=2,3,4$, при $r=2 s=3,4$, при $r \quad 3 s=4$, тобто визначають прирости: $h_{k}^{1 \rightarrow 2}, h_{k}^{1 \rightarrow 3}, h_{k}^{1 \rightarrow 4}, h_{k}^{2 \rightarrow 3}, h_{k}^{2 \rightarrow 4}, h_{k}^{3 \rightarrow 4}$.

Eman 6. Визначення величини сумарного приросту (зниження) показників у результаті переходу системи від $r$-тої до $s$-тої структури:

$$
h^{r \rightarrow s}=\sum_{k=1}^{4} h_{k}^{r \rightarrow s},
$$

де індекси $r$ i $s$ змінюють за правилом етапу 5.

Eman 7. Побудова графа, ребра якого від ображають процес переходу від $r$-тої до $s$-тої структури системи, а їхні ваги визначають згідно з (7).

Параметр кожної 3 вершин графа, що $\epsilon$ кількісною характеристикою відносної переваги даної ОС системи порівняно з іншими, визначають за формулами:

$$
\begin{aligned}
& w_{1}=h^{1 \rightarrow 2}+h^{1 \rightarrow 3}+h^{1 \rightarrow 4}, w_{2}=h^{1 \rightarrow 2}+h^{2 \rightarrow 3}+h^{2 \rightarrow 4}, \\
& w_{3}=h^{1 \rightarrow 3}+h^{2 \rightarrow 3}+h^{3 \rightarrow 4}, w_{4}=h^{1 \rightarrow 4}+h^{2 \rightarrow 4}+h^{3 \rightarrow 4} .
\end{aligned}
$$

Eman 8. Визначення оптимальної організаційної структури системи:

$$
w^{o p t}=\max \left\{w_{k}\right\}_{k=1,2,3,4} .
$$

\section{5. Апробація результатів дослідження}

Розглянемо процедуру оптимізації організаційної структури системи керування промисловим підприємством ТОВ «Завод «Красилівмаш», наявну схему якої наведено на рис. 1, а ії граф - на рис. 2.

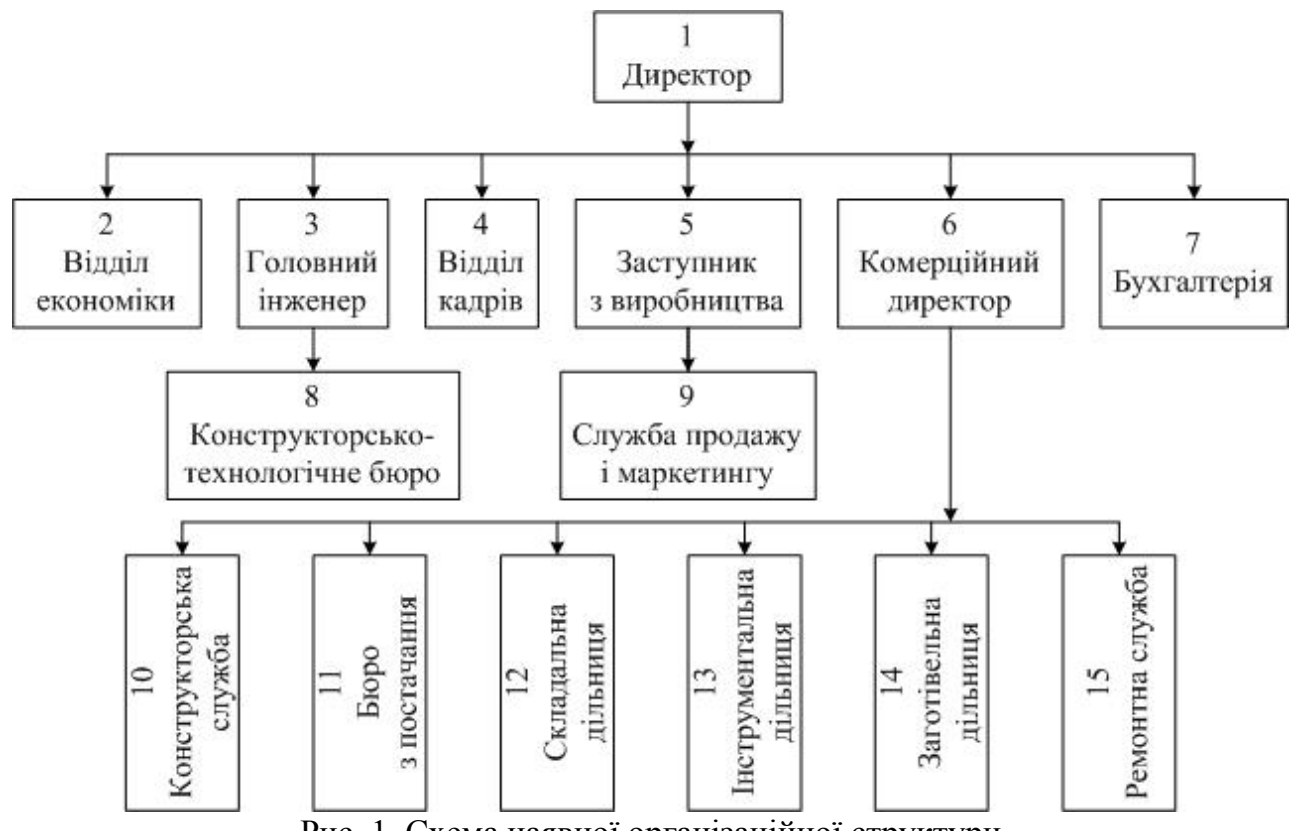

Рис. 1. Схема наявної організаційної структури

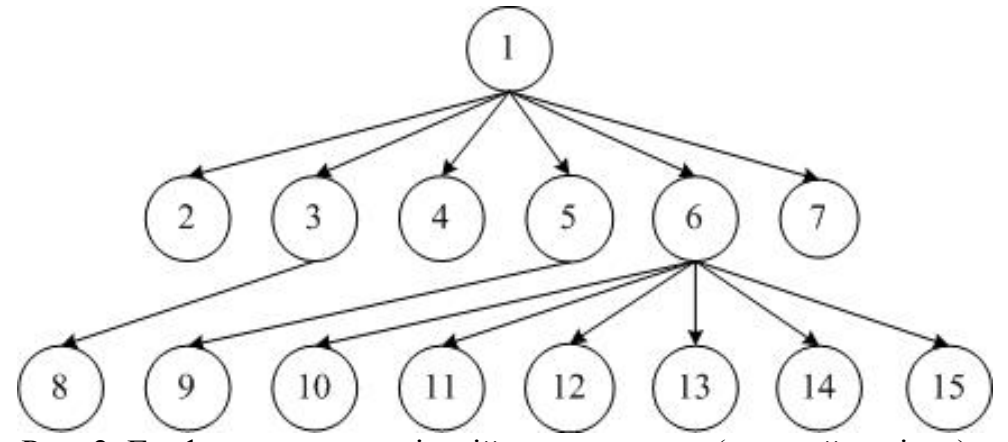

Рис. 2. Граф наявної організаційної структури (перший варіант)
Наведені на рис. 2 зв'язки відображають спрямованість відповідних управлінських рішень, а потоки інформації про стан кожного 3 підрозділів для керівних органів підприємства мають зворотні напрями.

3 метою вдосконалення наявної структури розглядають іiі альтернативні варіанти. За першим 3 них передбачають виключити зв'язок між елементами 6 i 10 і створити зв'язок між елементами 3 і 10, тим 
самим зменшивши кількість підлеглих комерційного директора (елемент 6), що $є$ перевантаженим за наявної структури, та включити в структуру зв'язок елементу 3 з елементом 6 для забезпечення обміну інформацією між комерційним директором та головним інженером. Організаційну структуру 3 цими змінами наведено на рис. 3.

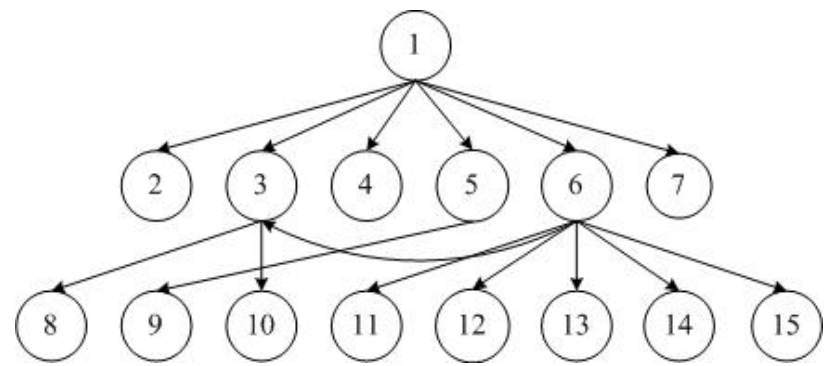

Рис. 3. Другий варіант графа організаційної структури

За другим альтернативним варіантом пропонується включити в структуру додатковий елемент (16) - фінансового директора та його зв'язки 3 відділом економіки (2), заступником директора 3 виробництва (5), комерційним директором (6) і бухгалтерією (7), виключивши при цьому зв'язки елементу 1 з елементами 2 і 7. Граф цього варіанта структури наведено на рис. 4.

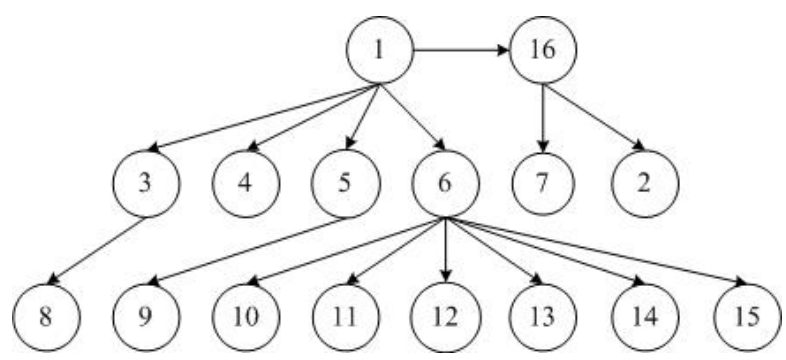

Рис. 4. Третій варіант графа організаційної структури

Четвертим варіантом (рис. 5) є організаційна структура, що об'єднує два попередні іiі варіанти, тобто включає фінансового директора та перехід функції керування конструкторською службою до головного інженера.

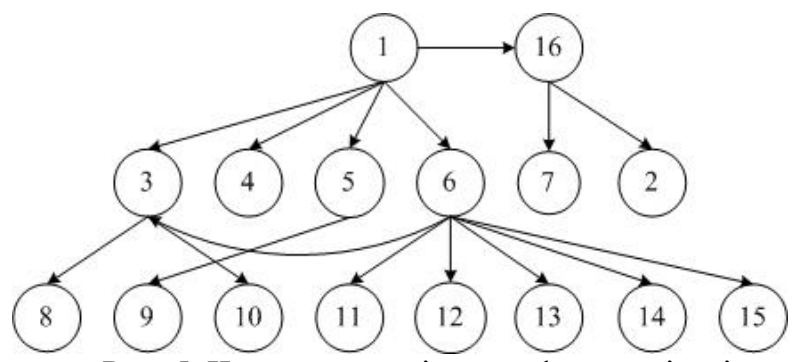

Рис. 5. Четвертий варіант графа організаційної структури

Задача оптимізації організаційної структури системи керування підприємством полягає у виборі найкращого 3 чотирьох наведених іiі альтернативних варіантів за комплексом критеріїв (1)-(4).
Побудовані графи структури не мають багатозв'язних вершин, тому немає потреби у побудові матриці мінімальних відстаней $X^{*}$ (етап 1). У зв'язку з цим $M_{\min }$ дорівнює фактичній кількості зв'язків між елементами структури.

Після здійснення оптимізації структури за кожним 3 критеріїв розраховують значення критеріальних показників для кожної структури без урахування інших критеріальних показників (етап 2) (табл. 1).

Таблиця 1

Значення критеріальних показників

\begin{tabular}{|c|c|c|c|c|}
\hline \multirow{2}{*}{$\begin{array}{c}\text { Варіант } \\
\text { структури }\end{array}$} & \multicolumn{4}{|c|}{ Значення критеріального показника } \\
\cline { 2 - 5 } & $f_{1}$ & $f_{2}$ & $f_{3}$ & $f_{4}$ \\
\hline 1 & 0 & 2,73 & 0,893 & 0,86 \\
\hline 2 & 0,005 & 2,79 & 0,907 & 0,75 \\
\hline 3 & 0,009 & 2,62 & 0,887 & 0,76 \\
\hline 4 & 0,013 & 2,61 & 0,892 & 0,88 \\
\hline
\end{tabular}

Ураховуючи, що показники мають різний економічний зміст і різну розмірність, виконують нормалізацію їх, результати якої наведено в табл. 2.

Таблиця 2

Нормалізовані значення критеріальних показників

\begin{tabular}{|c|c|c|c|c|}
\hline \multirow{2}{*}{$\begin{array}{c}\text { Варіант } \\
\text { структури }\end{array}$} & \multicolumn{4}{|c|}{$\begin{array}{c}\text { Нормалізоване значення } \\
\text { критьльног показника }\end{array}$} \\
\cline { 2 - 5 } & $f_{1}$ & $f_{2}$ & $f_{3}$ & $f_{4}$ \\
\hline 1 & 0 & 0,67 & 0,3 & 0,85 \\
\hline 2 & 0,38 & 1 & 1 & 0 \\
\hline 3 & 1 & 0,06 & 0 & 0,08 \\
\hline 4 & 1 & 0 & 0,25 & 1 \\
\hline
\end{tabular}

За цими значеннями критеріальних показників визначають величини $h_{\mathrm{k}}^{r \rightarrow s}$, на підставі яких розраховують величини сумарного приросту (зниження) показників у результаті таких переходів $\left(h^{r \rightarrow s}\right)$ (етапи 5 і 6):

$$
\begin{gathered}
h^{1 \rightarrow 2}=(0,38-0)-(1-0,67)-(1-0,3)+(0-0,85)=-1,5 ; \\
h^{1 \rightarrow 3}=(1-0)-(0,06-0,67)-(0-0,3)+(0,08-0,85)=1,14 ; \\
h^{1 \rightarrow 4}=(1-0)-(0-0,67)-(0,25-0,3)+(1-0,85)=1,87 ; \\
h^{2 \rightarrow 3}=(1-0,38)-(0,06-1)-(0-1)+(0,08-0)=2,64 ; \\
h^{2 \rightarrow 4}=(1-0,38)-(0-1)-(0,25-1)+(1-0)=3,37 ; \\
h^{3 \rightarrow 4}=(1-1)-(0-0,06)-(0,25-0)+(1-0,08)=0,73 . \\
\text { За за значеннями отриманих величин }
\end{gathered}
$$
визначають параметри вершин графа $\left(w_{k}\right)$ :

$$
\begin{gathered}
w_{1}=1,5-1,14-1,87=-1,51 ; \\
w_{2}=-1,5-2,64-3,37=-5,51 ; \\
w_{3}=1,14+2,64-0,73=3,05 ; \\
w_{4}=1,87+3,37+0,73=5,97,
\end{gathered}
$$

які використовують для побудови графа переходів організаційних структур, вершинами якого $\epsilon w_{k}$, а ребрами $-h^{r \rightarrow s}$ (рис. 6). 


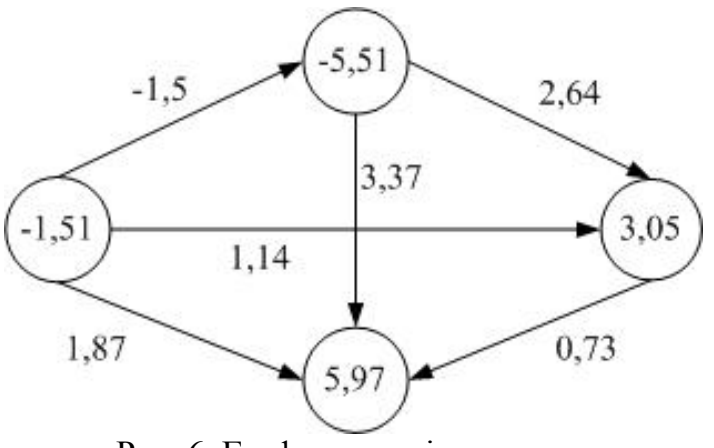

Рис. 6. Граф переходів структур
Оскільки за умовою (8) $\max w$ складає 5,97, то оптимальною за Парето організаційну структуру системи керування підприємством є іiї четвертий варіант, схему якого наведено на рис. 7.

У розглянутому прикладі не наведені конкретні значення величин $R$ та елементів матриць $A$ і $B$, що не $\epsilon$ принциповим для розуміння методу оптимізації організаційної структури. На практиці ці величини задаються індивідуально для конкретних підприємств.

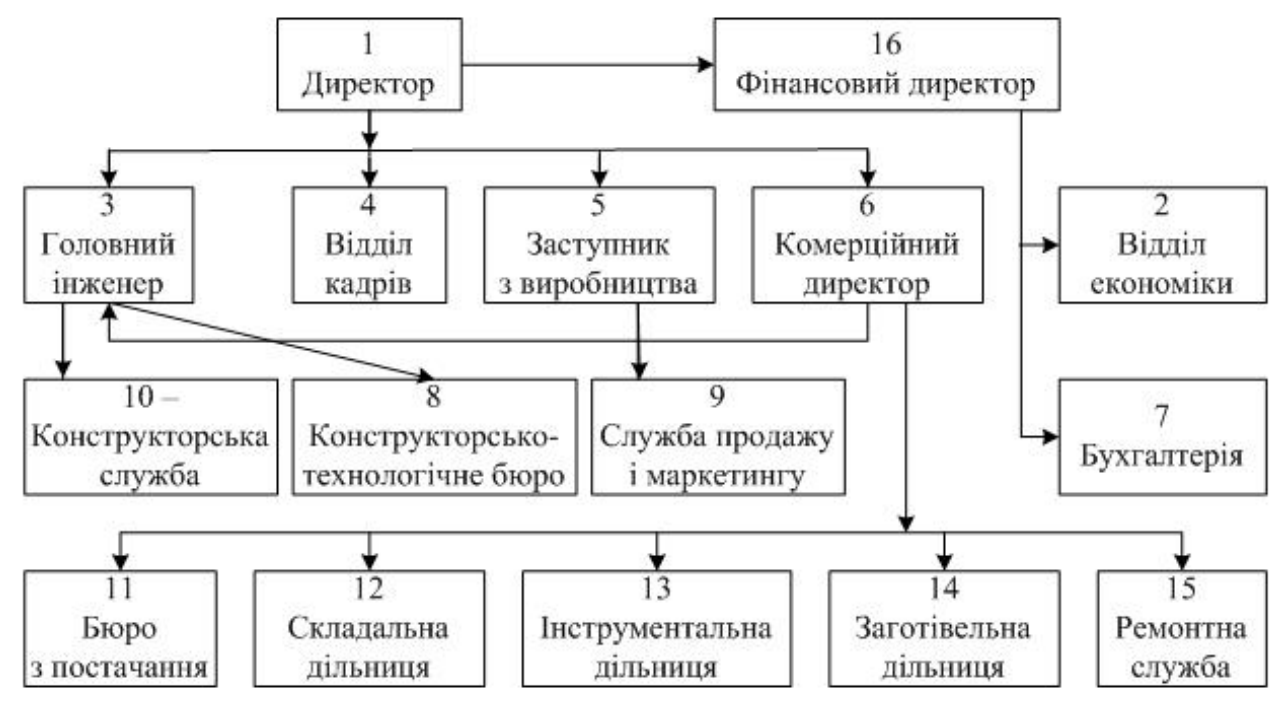

Рис. 7. Схема оптимальної організаційної структури системи керування

\section{6. Висновки}

Використання методу прийняття рішень на основі графа Паретто-оптимального управління дає змогу оптимізувати організаційну структуру системи керування, що становить оптимальний компромісний вибір. Переваги цього методу полягають у можливості оптимізації структури за комплексом неоднорідних критеріїв 3 урахуванням характерних для об'єкта керування обмежень шляхом компромісного вибору структури, що дозволяє адекватно врахувати всі вимоги до результатів іï функціонування.

\section{Література}

1. Акбердин, Р. 3. Совершенствование структуры, функций и экономических взаимоотношений управленческих подразделений предприятий при формах хозяйствования [Текст] : уч. пос. / Р. З. Акбердин, А. Я. Кибанов. М.: ГАУ, 2010. $-651 \mathrm{c}$.

2. Ансофф, И. Стратегическое управление [Текст] / И. Ансофф. - М.: Экономика, 1989. - 265 с.

3. Бурков, В. Н. Введение в теорию управления организационными системами [Текст]: учеб. / В. Н. Бурков, Н. А. Коргин, Д. А. Новиков. - М.: Либроком, 2009. - 264 с.

4. Евенко, Л. И. Организационные структуры управления промышленными корпорациями США (теория и практика формирования) [Текст] / Л. И. Евенко. - М.: Наука, 1983. - 350 с.

5. Новиков, Д. А. Теория управления организационными системами [Текст] / Д. А. Новиков. - М.: Издво физико-матем. лит-ры, 2012. - 604 с.
6. Овсиевич, Б. Л. Модели формирования организационных структур [Текст] / Б. Л. Овсиевич. - Л.: Наука, 1979. - 160 с.

7. Румянцева, 3. П. Менеджмент организации [Текст] / 3. П. Румянцева. М: Инфра-М, 1997. - 395 с.

8. Зыкова, А. А. Основы теории графов [Текст] / А. А. Зыкова. - М.: Наука, 1987. -344 с.

9. Клевцов, С. И. Компьютерная поддержка оперативного управления в организационных структурах [Текст] / С. И Клевцов, А. Б. Клевцова. - Таганрог: ТРТУ, 1999. $-90 \mathrm{c}$.

10. Гераськин, М. И. Формирование управления поликорпоративной системой при нескольких критериях эффективности на основе графа управлений [Текст] / М. И. Гераськин // Изв. Самарского науч. центра Рос. акад. наук. - 2003. - Т. 3. - С. 134-142.

\section{References}

1. Akberdin, R. Z., Kibanov, R. Y. (2010). Improving the structure, function and management of economic relations departments in companies with management practices. Moscow: State Academy of Management, 651.

2. Ansoff, I. (1989). Strategic Management. Moscow: Economics, 265.

3. Burkov, V. N., Korgin, N. A., Novikov, D. A. (2009). Introduction to management of organizational systems. Moscow, Librokom, 264.

4. Yevenko, L. I. (1983). Organizational structure of industrial corporations in the USA (the theory and practice of formation). Moscow: Scince, 350. 
5. Novikov, D. A. (2012). Theory of control of organizational systems. Moscow: Publisher physical and mathematical literature, 604 .

6. Ovsievich, B. L. (1979). Models of organizational structures. Leningrad: Scince, 160.

7. Rumyantseva, Z. P. (1997). Organizational Management. Moscow: Infra-M, 395.

8. Zykova, A. A. (1987). Fundamentals of graph theory. Moscow: Scince, 344.
9. Klevtsov, S. I., Klevtsova, A. B. (1999). Computer support of operational management in the organizational structures. Taganrog: Taganrog Radio Engineering University, 90.

10. Geras'kin, M. I. (2003). Formation of corporate management field system at several performance criteria based on graph controls. Proceedings of the Samara Scientific Center of the Russian Academy of Sciences, 3, 134-142.

Дата надходження рукопису 27.01.2015

Галіцин Володимир Костянтинович, доктор економічних наук, професор. кафедра інформаційного менеджменту. Київський національний економічний університет імені Вадима Гетьмана, Львівська площа, 14, м. Київ, Україна, 04053

E-mail: i42@kneu.kiev.ua

Суслов Олег Павлович, доктор економічних наук, професор, кафедра інформаційного менеджменту, Київський національний економічний університет імені Вадима Гетьмана. Львівська площа, 14, м. Київ, Україна, 04053

E-mail: suslov_@mail.ru

Остапчук Ольга Василівна, кандидат економічних наук. кафедра автоматизованих систем та моделювання в економіці. Хмельницький національний університет, вул. Кам'янецька, 110, м. Хмельницький, Україна, 29016

E-mail: z_olyska@ukr.net

УДК 2964

DOI: $10.15587 / 2313-8416.2015 .37213$

\title{
ОСОБЕННОСТИ РАЗВИТИЯ РЫНКА ЦЕННЫХ БУМАГ В АЗЕРБАЙДЖАНЕ
}

\author{
(C) Абдинов Рамиз Мобил оглы, Тагизаде Севиндж Сакит кызы
}

Наличие денег в национальной экономике приводит к формированию финансовой системы. Учитывая то, что главной функцией финансов является перераспределение, развитие финансовых рынков является основным условием механизма эффективного перераспределения. Финансовые рынки с целью нормального развития национальной экономики обеспечивают мобилизацию временно свободных денежных капиталов физических и юридических лии с коммерческой деятельности и распределение их между различными секторами экономики

Ключевые слова: иченная бумага, акция, облигачия, вексель, РЕПО и анти-РЕПО, клиринг, брокер, дилер, фондовая биржа, дивиденд, ноты, акционерные общества

The availability of money in the national economy leads to formation of financial system. Taking into account the fact that the main function of finance is redistribution, development of financial markets is an essential condition of effective redistribution mechanism. Financial markets to the normal development of the national economy provide the mobilization of temporarily free money capital of individuals and entities with commercial activities and their distribution among the various sectors of the economy

Keywords: securities, share, bonds, bills, repurchase agreement and anti-repurchase agreement, clearing, broker, dealer, stock exchange, dividend, notes, joint stock companies

\section{1. Введение}

Наличие денег в национальной экономике приводит к формированию финансовой системы. Учитывая то, что главной функцией финансов является перераспределение, развитие финансовых рынков является основным условием механизма эффективного перераспределения.

Рынок ценных бумаг состоит из первичного и вторичного рынков. На первичном рынке мобилизация финансовых ресурсов осуществляется за счёт выпуска ценных бумаг (эмиссия). В этом случае размещение ценных бумаг на рынке осуществляется двумя путями. В первом случае, размещающий ценные бумаги (эмитент) обращается непосредственно к инвесторам и путем распределения ценных бумаг между ними мобилизует финансовые средства. Во втором же случае, размещение (реализация) ценных бумаг осуществляется через посредников.

Ценные бумаги, размещённые на первичном рынке, покупаются и продаются на вторичном. В случае, когда первичный рынок является источником мобилизации средств для финансирования реального сектора, вторичный рынок, в основном, приводит к перераспределению богатства. Тем не менее, 